\title{
ESHAP chemotherapy is efficient in refractory/ relapsed primary central nervous system lymphoma: report of four cases
}

This article was published in the following Dove Press journal:

OncoTargets and Therapy

I October 2015

Number of times this article has been viewed

\author{
Rodica Ungur ${ }^{1,2}$ \\ Adrian Tempescul ${ }^{3}$ \\ Christian Berthou ${ }^{3}$ \\ Cristina Bagacean ${ }^{1,2}$ \\ Doinel Radeanu' \\ Adriana Muresan' \\ Mihnea Zdrenghea ${ }^{1,2}$ \\ 'Department of Hematology, Iuliu \\ Hatieganu University of Medicine \\ and Pharmacy Cluj, ${ }^{2}$ Department of \\ Hematology, Ion Chiricuta Oncology \\ Institute, Cluj-Napoca, Romania; \\ ${ }^{3}$ Department of Clinical Hematology, \\ Institute of Cancerology and \\ Hematology, Brest Teaching Hospital, \\ Brest, France
}

\begin{abstract}
Primary central nervous system non-Hodgkin's lymphoma is a rare presentation, almost always of diffuse large B-cell type. Although there is no consensus regarding therapy for this condition, induction regimens are based on high-dose methotrexate and consolidation whole-brain radiotherapy, or, more preferred recently, blood-brain barrier penetrating drugs such as etoposide, cytarabine, and alkylating agents like temozolomide, ifosfamide, and lomustine. We present here four cases of relapsed/refractory primary central nervous system lymphoma treated with ESHAP (etoposide, solumedrol, high-dose cytarabine, and platinum) chemotherapy to complete remission, with the eligible patients proceeding to autologous transplantation. We want to draw attention to this interesting, relatively well tolerated, underused therapeutic option, in a setting where treatment options are scarce and evidence-based recommendations are lacking.
\end{abstract}

Keywords: cerebral lymphoma, PCNSL, refractory, relapsed, platinum

\section{Introduction}

Although non-Hodgkin's lymphoma is a frequent cancer worldwide, primary central nervous system lymphoma (PCNSL) is a rare malignancy, with an incidence of less than 0.5 per 100,000 persons-years in the Western world. ${ }^{1}$ In more than $90 \%$ of cases, it has the histological features of a diffuse large B-cell lymphoma (DLBCL). Because of its low incidence, high grade evidence from large studies is lacking, and current management is based on reports on rather small cohorts. Evidence is even scarcer in the relapsed/refractory setting. The current standard first-line treatment for PCNSL consists of high-dose methotrexate (MTX) in combination with a variety of drugs and consolidation whole-brain radiotherapy, the latter being progressively replaced by chemotherapy. ${ }^{2}$ For patients relapsing after first-line treatment, intensive chemotherapy with autologous stem cell support is a feasible and relatively safe salvage therapy. For elderly patients, not able to withstand autografting, the second line of treatment is more controversial.

ESHAP (etoposide, solumedrol, high-dose cytarabine, and platinum) chemotherapy has been found to be an effective salvage regimen for nodal B-cell and Hodgkin's lymphomas and is accepted as an induction treatment before autografting. The regimen includes drugs known to be able to penetrate the blood-brain barrier ${ }^{3}$ and used for the treatment of cerebral tumors or metastases.

Here, we describe four cases of patients with PCNSL, either relapsed or refractory to first-line treatment, in which the induction with ESHAP chemotherapy allowed the achievement of a complete remission. Autologous stem cell transplantation under
Correspondence: Mihnea Zdrenghea Department of Hematology, Ion

Chiricuta Oncology Institute, 73, 21

Decembrie Boulevard, 400I24 Cluj-

Napoca, Romania

Tel +40264 43I 605

Fax +40264598606

Email mzdrenghea@umfcluj.ro 
Table I Outcome after ESHAP therapy with and without autologous stem cell transplantation in four patients with relapsed/refractory PCNSL

\begin{tabular}{|c|c|c|c|c|c|c|c|}
\hline Patient & $\begin{array}{l}\text { Age } \\
\text { (years) }\end{array}$ & $\begin{array}{l}\text { Initial } \\
\text { treatment }\end{array}$ & $\begin{array}{l}\text { Status after } \\
\text { initial treatment }\end{array}$ & $\begin{array}{l}\text { Localization at } \\
\text { relapse }\end{array}$ & $\begin{array}{l}\text { Time to relapse } \\
\text { (months) }\end{array}$ & $\begin{array}{l}\text { ESHAP } \\
\text { cycles to CR }\end{array}$ & $\begin{array}{l}\text { Outcome after salvage } \\
\text { therapy }\end{array}$ \\
\hline $\mathrm{I}$ & 57 & $\begin{array}{l}4 \mathrm{MBVP}+ \\
3 \mathrm{AraC}+\text { Ifo } \\
2 \mathrm{AraC}+\mathrm{VPI} 6\end{array}$ & $\begin{array}{l}\text { Progressive } \\
\text { disease }\end{array}$ & Left parietal & 1 & 2 & $\begin{array}{l}\text { In CR, } 30 \text { months after } \\
\text { ASCT }\end{array}$ \\
\hline 2 & 62 & $\begin{array}{l}4 \mathrm{MBVP}+ \\
3 \mathrm{AraC}+\text { Ifo } \\
2 \mathrm{AraC}+\mathrm{VPI} 6\end{array}$ & $\begin{array}{l}\text { Complete } \\
\text { remission }\end{array}$ & Left parietal & 24 & 1 & $\begin{array}{l}\text { Relapsed after } 8 \text { months, } \\
\text { deceased at } 12 \text { months }\end{array}$ \\
\hline 3 & 78 & $\begin{array}{l}4 \mathrm{MBVP}+ \\
3 \mathrm{AraC}+\text { Ifo } \\
2 \mathrm{AraC}+\mathrm{VPI} 6\end{array}$ & $\begin{array}{l}\text { Progressive } \\
\text { disease }\end{array}$ & Suprapeduncular & I & 1 & $\begin{array}{l}\text { Deceased after } 8 \text { months } \\
\text { (not lymphoma related) }\end{array}$ \\
\hline 4 & 70 & $\begin{array}{l}4 \mathrm{MBVP}+ \\
3 \mathrm{AraC}+\text { Ifo } \\
2 \mathrm{AraC}+\mathrm{VPI} 6\end{array}$ & $\begin{array}{l}\text { Complete } \\
\text { remission }\end{array}$ & Suprapeduncular & 14 & 2 & $\begin{array}{l}\text { Relapsed after } 10 \text { months, } \\
\text { deceased at } 12 \text { months }\end{array}$ \\
\hline
\end{tabular}

Abbreviations: ESHAP, etoposide, solumedrol, high-dose cytarabine, and platinum; PCNSL, primary central nervous system lymphoma; CR, complete remission; ASCT, autologous stem cell transplantation; MBVP, methotrexate, carmustine, etoposide, methyl prednisolone; Ifo, ifosfamide.

optimal conditions for the younger patients was thus possible. For the two elder patients, consolidation therapy using the same regimen was continued. The Institutional Review Board does not require ethical approval for case reports. All patients signed informed consent forms.

During a calendar year (2011), we identified four patients. All were HIV negative and treated for PCNSL with standard high-dose MTX therapy using the local protocol: induction therapy consisting of four cycles of MBVP (MTX, carmustine, etoposide, methyl prednisolone) followed by consolidation with three cycles of ifosfamide plus cytarabine and two cycles of cytarabine and etoposide (no radiotherapy), either refractory or relapsed within 2 years after completion of treatment. Patients' characteristics are presented in Table 1.

At relapse, the patients were given ESHAP chemotherapy every 21 days. Dose adjustment was made for the elder patients, according to the local protocol requiring a $30 \%$ reduction of etoposide, cytarabine, and platinum doses for patients with performance status $>1$. An evaluation by computed topography (CT) scan or magnetic resonance imaging (MRI) was performed on day 1 of each cycle of chemotherapy. The patients received primary granulocyte colony stimulating factor prophylaxis for neutropenia from day 8. Tolerance of the treatment was good; only one patient (the oldest) presented infectious events and required hospitalization. Complete remission of cerebral lesions was seen in all the four patients, after the first or the second cycle of chemotherapy. The two younger patients (below 65 years) underwent stem cell mobilization and peripheral blood harvest after a third cycle of ESHAP chemotherapy. A maximum of two apheresis sessions were required to obtain $>3 \times 10^{6}$
$\mathrm{CD} 34^{+}$cells $/ \mathrm{kg}$. The patients then proceeded to autologous stem cell transplantation (standard BEAM conditioning).

\section{Discussion}

PCNSL is a rare disease, representing less than $2 \%$ of all the cases of non-Hodgkin's lymphoma. Its incidence increases with age, with a median age of $60-70$ years. ${ }^{4}$ Also, there has been a surge in HIV-related PCNSL cases in the nineties, receding during the last decade. ${ }^{1,5}$ The presentation differs in terms of localization, dimension and number of tumors, symptoms varying from an intermittent neurological dysfunction to rapid impairment of neurological or cognitive functions. PCNSL most frequently presents as a DLBCL with typical perivascular localization, differing from DLBCL of other localization. Other histological subtypes of cerebral lymphoma are very rare. ${ }^{6}$

It is now well established that the first-line treatment for PCNSL is based on an association of high doses of MTX with other drugs, with or without whole-brain radiotherapy. For refractory or relapsed cases, several regimens have been proposed. Treatment with temozolomide, topotecan, carboplatin, and cytarabine achieve response rates of $26 \%-37 \%{ }^{7}$ Autologous stem cell transplantation is an important therapeutic option in these patients, allowing for an increase in overall survival. ${ }^{8}$

Cisplatin-based ESHAP chemotherapy has for a long time demonstrated efficacy in refractory/relapsed patients with DLBCL. ${ }^{9}$ Soussain et al proved in a cohort of 65 patients with relapsed/refractory DLBCL (including 27 patients with bone marrow or CNS involvement, but not PCNSL) that ESHAP chemotherapy is effective, allowing for peripheral 
stem cell harvest and autologous stem cell transplantation. ${ }^{10}$ It has also been proven that ESHAP chemotherapy could be administrated in elderly patients without significant toxicity. ${ }^{11}$ Platinum-based chemotherapy is also effective in infant brain tumors. ${ }^{12}$

Use of ESHAP in PCNSL has been rarely reported, most notably in a French retrospective study of 22 immunocompetent patients with relapsed/refractory disease, of which five received rituximab (R)-ESHAP, two obtaining a complete and one a partial remission. The rest received dexamethasone, high dose aracytine, and cisplatin $+/-\mathrm{R}$, to an overall complete remission rate of $27 \% .{ }^{13}$ In our patients, the use of ESHAP chemotherapy resulted in rapid regression of symptoms and disappearance of lesions observed in CT or MRI scans. The treatment was well tolerated; the two younger patients were stem cell mobilized, and then autologous stem cell transplantation was performed in optimal conditions. The two elderly patients continued with two additional cycles of the same regimen as consolidation therapy.

We saw a remarkable effectiveness of ESHAP chemotherapy in our patients, previously treated with high doses of MTX, cytarabine, etoposide, and corticosteroids. Although this is a report of a small series of patients, we propose ESHAP chemotherapy as an efficient and well-tolerated salvage regimen, ideally followed by autologous stem cell transplantation, in relapsed/refractory primary CNS lymphoma. Obviously, as with all PCNSL treatments, there is a need for larger, prospective trials to yield higher grade evidence allowing for stronger recommendations.

\section{Acknowledgments}

Dr R Ungur acknowledges support under the frame of European Social Fund, Human Resources Development Operational Program 2007-2013, Project No.POSDRU/159/1.5/ $\mathrm{S} / 138776$, Drs Zdrenghea and Bagacean from Grant CNCS-UEFISCDI, Project Number PN-II-RU-PD-20113-0277, and Dr Zdrenghea from Grant 1494/2014 from the University of Medicine and Pharmacy Cluj. The sponsors had no involvement in the collection, analysis and interpretation of data, in the writing of the manuscript, and in the decision to submit the manuscript for publication.

\section{Disclosure}

The authors report no conflicts of interest in this work.

\section{References}

1. Villano JL, Koshy M, Shaikh H, Dolecek TA, McCarthy BJ. Age, gender, and racial differences in incidence and survival in primary CNS lymphoma. Br J Cancer. 2011;105(9):1414-1418.

2. Rubenstein JL, Gupta NK, Mannis GN, Lamarre AK, Treseler P. How I treat CNS lymphomas. Blood. 2013;122(14):2318-2330.

3. Muldoon LL, Soussain C, Jahnke K, et al. Chemotherapy delivery issues in central nervous system malignancy: a reality check. JClin Oncol. 2007; 25(16):2295-2305.

4. Olson JE, Janney CA, Rao RD, et al. The continuing increase in the incidence of primary central nervous system non-Hodgkin lymphoma: a surveillance, epidemiology, and end results analysis. Cancer. 2002; 95(7):1504-1510.

5. O'Neill BP, Decker PA, Tieu C, Cerhan JR. The changing incidence of primary central nervous system lymphoma is driven primarily by the changing incidence in young and middle-aged men and differs from time trends in systemic diffuse large B-cell non-Hodgkin's lymphoma. Am J Hematol. 2013;88(12):997-1000.

6. Montesinos-Rongen M, Siebert R, Deckert M. Primary lymphoma of the central nervous system: just DLBCL or not? Blood. 2009;113(1):7-10.

7. Sierra del Rio M, Rousseau A, Soussain C, Ricard D, Hoang-Xuan K Primary CNS lymphoma in immunocompetent patients. Oncologist. 2009;14(5):526-539.

8. Soussain C, Hoang-Xuan K, Taillandier L, et al. Intensive chemotherapy followed by hematopoietic stem-cell rescue for refractory and recurrent primary CNS and intraocular lymphoma: Societe Francaise de Greffe de Moelle Osseuse-Therapie Cellulaire. J Clin Oncol. 2008;26(15):2512-2518.

9. Velasquez WS, McLaughlin P, Tucker S, et al. ESHAP - an effective chemotherapy regimen in refractory and relapsing lymphoma: a 4-year follow-up study. J Clin Oncol. 1994;12(6):1169-1176.

10. Soussain C, Souleau B, Gabarre J, et al. Intensive chemotherapy with hematopoietic cell transplantation after ESHAP therapy for relapsed or refractory non-Hodgkin's lymphoma. Results of a single-centre study of 65 patients. Leuk Lymphoma. 1999;33(5-6):543-550.

11. Aviles A, Neri N, Huerta-Guzman J, de Jesus Nambo M. ESHAP versus rituximab-ESHAP in frail patients with refractory diffuse large B-cell lymphoma. Clin Lymphoma Myeloma Leuk. 2010;10(2):125-128.

12. Fouladi M, Gururangan S, Moghrabi A, et al. Carboplatin-based primary chemotherapy for infants and young children with CNS tumors. Cancer. 2009;115(14):3243-3253.

13. del Rio MS, Choquet S, Hoang-Xuan K, et al. Platine and cytarabinebased salvage treatment for primary central nervous system lymphoma. J Neurooncol. 2011;105(2):409-414.
OncoTargets and Therapy

\section{Publish your work in this journal}

OncoTargets and Therapy is an international, peer-reviewed, open access journal focusing on the pathological basis of all cancers, potential targets for therapy and treatment protocols employed to improve the management of cancer patients. The journal also focuses on the impact of management programs and new therapeutic agents and protocols on

\section{Dovepress}

patient perspectives such as quality of life, adherence and satisfaction. The manuscript management system is completely online and includes a very quick and fair peer-review system, which is all easy to use. Visit http://www.dovepress.com/testimonials.php to read real quotes from published authors. 